\title{
Projeto Tucuruí
}

\author{
CNPq/INPA - ELETRONORTE
}

A Usina Hidrelétrica de Tucciruí está situada no rio Tocantins, no Estado do Pará, logo a montante da cidade de Tucuruí, distante aproximadamente $300 \mathrm{~km}$ em linha reta, da cidade de Belém. A construção da barragem envolve a formação de um grande reservatório de cerca de $2.160 \mathrm{~km}^{2}$, com um volume de água acumulado da ordem de $43,0 \mathrm{x}$ $10^{9} \mathrm{~m}^{3}$. A superfície do lago atingirá o nível máximo maximorum de $74,0 \mathrm{~m}$, operando no entanto entre $72,0 \mathrm{~m}$ no máximo normal e $58,0 \mathrm{~m}$ no mínimo normal. A vazão do rio Tocantins é em média $9.208 \mathrm{~m}^{3} / \mathrm{s}$ com o mínimo observado de $1.511 \mathrm{~m}^{3} / \mathrm{s} \quad(08.10 .55)$ e o máximo de $51.512 \mathrm{~m}^{3} / \mathrm{s}$ (09.04.57), segundo os dados coletados entre 1949 e 1974 . Em 1980, no entanto, a descarga atingiu em março-abril o índice de $60.000 \mathrm{~m}^{3} / \mathrm{s}$, reafirmando a crença de que na Amazônia a grande seca e a grande cheia sempre ainda estão por vir.

Essas características básicas da Usina e do rio que será represado, aliadas à posição geográfica do empreendimento em plena floresta equatorial úmida, geram preocupações com os problemas relacionados com o desenvolvimento dessa obra de grande porte. Os efeitos potenciais sobre o ecossistema induziu a formulação de diretrizes básicas, no sentido de previsão, programação e ação continuada, como instrumento indispensável para conciliar as divergências que possam surgir entre as necessidades do desenvolvimento econômico e a imperiosidade de preservar o meio ambiente. Evidentemente que algum prejuízo ecológico resultará da atividade hidrelétrica mas apenas o acompanhamento detalhado das alterações pode produzir resultados indicativos para correções nas obras futuras. Como Tucuruí é o primeiro grande projeto de desenvolvimento da Amazônia, não há modelos a seguir, no sentido da proteção ambiental. Outras obras similares de médio e grande porte estão programadas para a região e o estabelecimento de um programa de pesquisa capaz de avaliar o impacto sobre o meio-ambiente era uma necessidade imperiosa.

Nesse sentido o INPA apresentou à ELETRONORTE uma proposta de estudo que finalmente resultou na celebração de um convênio entre o CNPq/INPA e as CENTRAIS ELETRICAS DO NORTE DO BRASIL "para a execução de estudos de ecologia e controle ambiental na região do Reservatório da UHE de Tucuruí". Dentro desse convênio, nove sub. projetos básicos serão desenvolvidos.

1. Estudo da qualidade da água.

1.1. parâmetros físico-químicos

1.2. parâmetros biológicos

1.3. potabilidade

1.4. nutrientes e eutroficação 
2. Ictiofauna.

3. Levantamento e controle de macrófitas aquáticas.

4. Levantamento e quantificação da vegetação a ser inundada em Tucuruí.

5. Estudo da degradação do material vegetal.

6. Levantamento, identificação e cadastramento da flora de Tucuruí.

7. Estudo do impacto do reservatório de Tucuruí no aumento das doenças endêmicas da região.

8. Estudọ meteorológico de Tucuruí.

9. Levantamento dos solos na área de influência do reservatório de Tucuruí.

Dessa forma, o INPA $€$ a ELETRONORTE assumem posição de vanguarda no estudo das barragens da região tropical úmida brasileira, fixando em Tucuruí o modelo de pesquisa ecológica para as hidrelétricas da Amazônia, buscando um discernimento claro e objetivo dos níveis de conseqüência da atividade da Usina. A busca de ação equilibrada que minimize ou evite os efeitos do grande lago e da represa sobre o ecossistema através do método científico, é provavelmente a tarefa pragmática de maior porte e alcance do INPA, na década de 80 .

Ozcrio d. M. Fonseca

Coordenador do Projeto Tucuruí 